\title{
CONSTRUCTING THE EPISTEMOLOGICAL ASPECT FIQH NUSANTARA
}

\author{
Moh. Mukri \\ State Islamic University of Raden Intan Lampung \\ Sukarame, Kota Bandar Lampung, 35131, Indonesia \\ E-mail:moh_mukri@yahoo.com \\ Imam Mustofa \\ State Islamic Institute (IAIN) Metro \\ East Metro, Metro, Lampung, 34112, Indonesia \\ E-mail: imammustofa472@yahoo.co.id \\ Fauzan \\ State Islamic University of Raden Intan Lampung \\ Sukarame, Kota Bandar Lampung, 35131, Indonesia \\ E-mail:fauzan@radenintan.ac.id
}

\begin{tabular}{c|c|c}
\hline Received: & Revised: & Approved: \\
02/04/2019 & $25 / 05 / 2019$ & $23 / 06 / 2019$ \\
\hline
\end{tabular}

DOI: http:/ /dx.doi.org/10.32332/akademika.v24i1.1617$$
\text { (c) (7) (2) }
$$

Constructing The Epistemology Of Nusantara Fiqh: A Proposal Licensed Under a Creative Commons Attribution-ShareAlike 4.0 International License
\end{abstract}

\begin{abstract}
This article proposes an epistemology of Nusantara Fiqh. Considering the fact that the majority of Indonesia's population is Muslim and that the tribes, ethnicities and religions are diverse, it is necessary to construct an epistemology of Indonesian Islamic law that is compatible with such a condition. The Indonesian Fiqh has its own characteristics. Fiqh and the study of Nusantara Islamic law must be based on an epistemology that considers that plurality. This study employed a qualitative approach with inductive analysis where the researcher created categories of various
\end{abstract}


themes and certain patterns from the research data. Then, the categories were formulated based on the records of existing data. The result of this study is the development of the Indonesian Islamic law epistemology using the istișlaachii model aimed at giving benefits for the Indonesian people by combining nas size or text with a logical view, communicating text and tradition (context). The integration of the two was done so that the benefits to be obtained adhere to the syara' and only use logical considerations and the social reality. The integration of nas and logical view was done so that ijtihad does not become textual dogma without considering realistic and practical benefits.

Keywords: Ushul Fiqh, Nusantara, and Epistemology

\section{A. Introduction}

Based on the view that Ushul Fiqh was systemized in the ear of Imam Syafi'i, it could be traced this branch of knowledge has reached 1300 years. Along such period of years, this Islamic methodology has certainly needs contextual and sociological mending and further development. The contemporary islamic scholars such as Hasan Al-Turabi, Muhammad 'Abid al-Jābirī, Hassan Hanāfí, Mohammed Arkoun with their latest discourses did offer to reconstruct Ushul Fiqh. ${ }^{1}$ The related reconstruction is necessary and crucial in order to face various Islamic law-related issues based on the apparatus and methodology of the field itself. With reconstruction of the Methodology, it is expected that Islamic law will be more responsive to the current days phenomena that keeps on growing and requires anwers from the perspective of Islamic law.

Once, Abdillah ${ }^{2}$ elaborated Indonesian Islamic law, specifically on jinayah. He viewd that the epistemology structure of Islamic law in Indonesia must alocate major proportion to cognition, history, tradition and local believes of Indonesia. Abdillah's proposal to endow portion to cognition in Islamic law epistemology is no novelty. Mustofa had also given his review on Islamic law epistemology based on Al-ghazali point of view. In his discussion, Mustofa concluded that Al-Ghazali has given his effort to construct a combination outline between the divine knowledge with ushul fiqh

1 Junaidi Abdillah, "Rekonstruksi Epistemologi Fiqh Jinâyah Indonesia Dan Relevansinya Bagi Pembangunan Hukum Nasional," $A L$ 'ADALAH 11, no. 2 (2013): 190.

2 Abdillah, " Rekonstruksi Epistemologi Fiqh Jinâyah Indonesia Dan Relevansinya Bagi Pembangunan Hukum Nasional." 
as well as the intergration of divine words and mortal cognition in Islamic law theory, though he was not the initiator of such action. It was Al-Ghazali who then continued the work of Imam Syafi'i, of whom had proven that there was no contradiction between the divine words and mortal cognition. ${ }^{3}$

The scientific epistemology of contemporary Islam has evolved and moved from the traditional Islamic epistemology itself. There is an integration effort in traditional epistemology which makes nash as a central point with contemporary methodologies involving contemporary social sciences and humanities and critical philosophy (Critical Philosophy). ${ }^{4}$ Meanwhile, Auda uses a multidimensional approach in developing contemporary Islamic epistemology. Related to the Islamic law, Auda is more emphasizing the renewal of the concept of Maqāsid al-Syariáh and making it as a base of thought for the development of Islamic law that deals with efforts to accommodate local culture and wisdom in a scientific circle. ${ }^{5}$

Furthermore, related to Islam and the culture of the archipelago, Hasib conducted towards the dialectics and cultural mix of the archipelago and Islam. Based on his study during the Wali Songo period, the phenomenon of "Mystical Synthesis" was found which is an Islamization in the sense of collaborating with local beliefs and culture, which then came "Neo-Sufism" whose orientation to Islam was more Islamic. At first, Islamic da'wah emphasized aspects of continuity between Islamic teachings and local culture, instead of making changes to local culture. This period instead adopted and affirmed local culture in the teaching system. It is supported by Islamic teachings that are very flexible, more on the aspects of substance and Islamic spirit, as well as the understanding of tasawwuf called wahdatul wujud, hulul which was felt by pantheistic local beliefs. Even though the "Neo-Sufism" thought made changes in the next periods, it remained in a slow and not radical rhythm, because "Mystical Synthesis" still exists today. ${ }^{6}$ (Tauhidi, 2015: 14-15).

3 Imam Mustofa, "Epistemology Hukum Islam dalam Perspektif alGhazali (Telaah atas f Kitab al-Mustashfa min 'Ulmul Ushul)," an -Nawa Jurnal Hukum Islam 4, no. 1 (t.t.): 2009.

${ }^{4} \mathrm{M}$ Amin Abdullah, "NEW BUILDING OF EVIDENCE EPISTEMOLOGY ISLAMIC LAW STUDY IN RESPONDING GLOBALIZATION," Ash-Syir'ah Journal of Shariah Sciences and Law 46 (2012): 326.

5332.

6 Hasib dalam N. Tauhidi Pizzaro, Islam Nusantara: Islamisasi Nusantara ataucMenusantarakan Islam? (Jakarta: T.tp, 2015), 14-15. 
This article proposes an epistemology of Nusantara Fiqh. Considering the fact that the majority of Indonesia's population is Muslim and that the tribes, ethnicities, and religions are diverse, it is necessary to construct an epistemology of Indonesian Islamic law that is compatible with such a condition. The Indonesian Fiqh has its own characteristics. Fiqh and the study of law in Islam Nusantara must be based on an epistemology that considers that plurality.

This study focused on a qualitative approach with library data as the main data that collected by using documentation. It was done by reading the discourse on the study of the epistemology of Islamic law and Islamic studies of the archipelago. Data had been collected and analyzed by using the content analysis method (content analysis), a technique that can be used to make inferences that can be replicated and validated by paying attention to the context. ${ }^{7}$ As a qualitative research, ${ }^{8}$ this study employed a qualitative approach with inductive analysis where the researcher created categories of various themes and certain patterns from the research data. Then, the categories were formulated based on the records of existing data.

\section{B. Concept of Islam Nusantara: Conseo and Characteristics}

Azra emphasized that the term of "Islam Nusantara" in an education world refers to "Southeast Asian Islam" which is found in the Muslim regions such as Indonesia, Malaysia, Brunei, Pattani (Southern Thailand) and Mindanau (Southern Philippines). The territory of Islam Nusantara in precolonial literature is called "Negeri Bawah Angin" (lands below the wind). In Arabic literature, it was called "bilad al-Jawi" (Jawi Muslim country) since the 16th century, Southeast Asia. The Islamic archipelago community is commonly referred to as "ashab al-Jawiyyin" or "Jama'ah alJawiyyin". The region of Islam Nusantara is one of the Eight religion-cultural realms of Islam that consisted of Arabic, Persian / Iranian, Turkish, Indian Continents, Sino Islamic, Black Africa and the Western World. Although holding the same basic principles and teachings in aqidah and worship, every domain has its own religious and cultural characteristics. ${ }^{9}$

7 Klaus Krippendorff, Content Analysis; an Introduction to Its Methodology (London: Sage Publication, 2004).

8 Norman K. Denzin dan Yvonna S. Lincoln, Hand Book of Qualitative Research (Yogyakarta: Pustaka Pelajar, 2009), 272.

9 Azyumardi Azra, "Sustainable Indonesian Islam," Kompas, 3 Agustus 2015. 
The word "Islam Nusantara" consists of "Islam" and "Nusantara", where the word "Islam" refers to a name of religion that is recognized by Muslims as its adherents, both outside and inside in the Republic of Indonesia. It makes Islam is the religion brought by Allah's last messenger, Muhammad (PBUH), religion was revealed to all prophets and apostles, both the former to the last. ${ }^{10}$ Religion and Islam regulate all aspects of human life, both of which are related to worship, faith, and human relations with creation as servants of Allah. The meaning of "Islam", literally, is "surrender" (al-istislam) to Allah. ${ }^{11}$ Complete Islamic teachings touch the invisible dimensions, such as faith in God, angels, heaven, hell and so on, where all of this becomes like trust, and also touches on the social, political, economic, cultural, neighboring, family, national, citizen dimensions countries, and so on in this world. All Islamic teachings and their development in changing time, conditions, environment, traditions and habits encourage the religious scholars to interpret Islamic teachings to be more in line with changing situations and conditions as recognized by not only a Muslim scholar, but that has become a kind of theory of change time by time. ${ }^{12}$ Therefore, Islam is believed to be the teachings appropriate in every era, as was said by the statement further: 13

$$
\text { نعتقد أن الإسلام دين ودولة, و عبادة وحكم وأنه صالح لكل زمان ومكان }
$$

"We believe that Islam is religion and state, religious and regulations. What is always appropriate and appropriate for every time and place"

Islam Nusantara brings imagination to diversity, difference, and pluralism. The archipelago is a diversity that does not recognize a single identity. Nusantara inhabitants inherit at least 10 diverse archipelago characters. Islam Nusantara is a multicultural Islam as we witness it in the archipelago, while Indonesia "demands" our imagination for unity. Even though we have only been able to unite, if we have acknowledged that we are different and diverse, and have

10 Muhammad bin Abdillah bin Shalih al- Sahim, al-Islam Usul wa Mabadi'uh (al-Mamlakah al-Arabiyah al-Su'udiyah, Wazair al-Syu'un alIslamiyah wa al-Auqaf wa al-Dakwah wa al-Irshad, 1421H), 217.

${ }_{11}$ Al-Shahib bin Ubad, al-Muhith fi al-Lughah, (tt.p: tt.t), volume 2, h. 365.

12 Abdurrahman bin Sa'ad al-Syhstariy, Taqnin al-Shari'ah Bain alTahlil wa al-Tahrim, t.t., 116.

13 Al-Nadwah al-Alamiyah 1syabab al-Islamiy, "al-Mausu'ah alMuyassarah fi al-Adyan wa al-Azahib wa al-Ahzab" volume 22 (t.t.): 6. 
the wisdom to accept all the pluralism, then we will be able to unite. We can unite in national identity, but that cannot be denied: Islamic understanding and expression remain plural and diverse. ${ }^{14}$

Understanding Islam Nusantara is an important thing to do because there are religious and cultural dimensions that are intertwined each other. This dimension is a way for Islam to compromise with territorial boundaries that have certain cultural roots. This resulted in Islam completely no longer present themselves as rigid and closed, exclusive and textual a sich, but respect the otherness, inclusive side-esoteric and touched poultice reality. Islam does appreciate the values of a particular geographical area. This is supported by Gus Dur by delivering that "The overlap between religion and culture will occur continuously as a process that will enrich life and make it is not barren". ${ }^{15}$

Regarding the characteristics of Islam Nusantara, has been attached to the naming of "Islam Nusantara" itself. Islam Nusantara is a special character that distinguishes it from other community organizations. Some of the characteristics of the Islam Nusantara itself are as follows: 16

First is Moderate-Anti Extreme. "His anti extreme moderate" typically in Arabic translated by the word "توسط" as found in a few sentences Muslim scholars as follows ${ }^{17}$

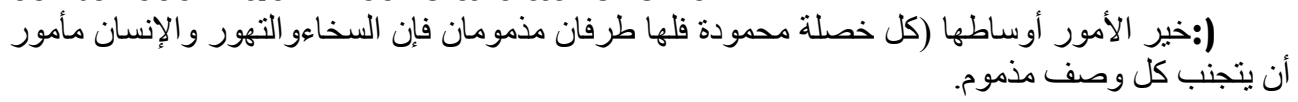

"The best place of all over is in the middle. Every end of the result has two bad peaks; in fact, generosity is in stinginess and wasteful behavior. Courage is in the midst of cowardice and carelessness. Humans are ordered to avoid evil away from him. far from him increasing, the empty attitude is also getting away from him "

14 Ahmad Syafii Maarif, Islam in the Frame of Indonesianness and Humanity: A Reflection of History (Bandung: Mizan Collaborating with the Maarif Institute, 2009), 305.

15 Akhmad Sahal, Nusantara Islam From Ushul Fiqh to Paham Kebangsaan (Bandung: Mizan Library, 2015), 33.

${ }^{16} \mathrm{KH}$ Musthofa Bisri, who is familiarly called Gus Mus, at the National Institute for Nusantara Studies (INNUS) seminar on Wednesday, November 18,2015 , which coincided with the building of the Da'wah of UIN Sunan Ampel Surabaya.

17 Abu al-Sa'adat al-Mubarak bin Muhammad al-Jaziriy, al-Nihayah fi Gharib al-Astar, vol. 5 (Baerut: al-Maktabah al-Ilmiyah, 1979), 299. 
Referring to the explanations above," moderate "is the best attitude in community life in the midst of problems that come, whether religious matters or others. This character is displayed by the term "Islam Nusantara" which makes it appear different from other organizations which were established by many as group identities as is known in any country.

Second is "tolerance". Tolerance is an attitude in Arabic called "نسامح", which is an attitude that emphasizes gentleness (friendliness) and ease as indicated by the following expression: ${ }^{18}$

$$
\begin{aligned}
& \text { إن التسامح هو اللين و التساهل نوع من أنو اع الإحسان إلى النفوس التي جبلت, لذا فإن إنسان التسامح يؤدي }
\end{aligned}
$$

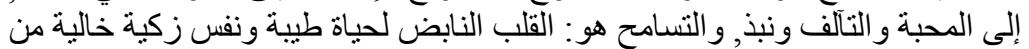

"Indeed, tolerance is an attitude that is gentle and easy Ibn alAthir said: tolerance is the convenience, and al-Fairuzabadiy said: "Be tolerant and easy." This is one kind of kindness in the soul that brings love for who is the best for the soul, therefore tolerance brings love and harmony, it also throws away violence and dissonance Tolerance is a heart that encourages to find a good life, a clear soul, free from all kinds of violence and extremes "

The third is" balanced and inclusive ". This characteristic is the main identity of "Islam Nusantara" found in the history of Islam in Indonesia when Islam was first introduced by Muslim scholars known as Sunan or Wali Songo "Nine guardians" as explained by Agus Sunyoto. He stated that the success of Islamization in Java on the 15th century was caused by the arrival of Muslims from Champa, such as Raden Rahmat (Sunan Ampel) in 1440. Furthermore, the success of Islamization was also supported by scholars relations in organized and systematic problems. They use family relationships and also display good morals so people are attracted to their attitudes. Therefore, the advantages of Islam Nusantara can be seen in four aspects, namely: 1. Sufism, 2. Assimilation of education, 3. Da'wah (art and culture), 4. Establishment of the Archipelago's society. 19

\section{Constructing the Epistemology of Nusantara Fiqh}

One of the rules that are fabulous among Islamic jurists is

18 Hikamat bin Basyir bin Yasin, Samahah al-Islam fi al-Ta'amul ma'a ghair al-Muslimin, t.t., 1.

19 Muhammad Guntur Ramli, Our Islam, Nusantara Islam Five Basic Values of Nusantara Islam, (: ), edition., h., 1 ed. (Tanggerang: Ciputat School, 50), 50. 
Regarding the above rules, Nusantara is interpreted geographically and environmentally will give new colors when intersected with Islamic law, especially the study or fiqh. Fiqh Nusantara is going to embrace various customs, cultures, and local wisdom of Nusantara. Moreover, this gives the legitimacy of the theorists of Islamic law in ushul fiqh through the concept of al-urf.

Islamic law (Syariah context) that has a relation between human and Allah, such as the procedures and provisions of sholat that should follow the rules of fiqh normatively. However, the communication among humans needs to be actualization so that the contextualization efforts can also be made which also use local culture and customs as considerations and legal propositions. ${ }^{20}$

Islamic law makes us believe that the law is not truly independent of jurisprudence. They are interrelated and interdependent. This also applies to the Islamic legal system. The Qur'an introduces Islam and its way of life as inclusive, universal and permanent, and beyond time and place. Therefore, Islam claims to be a complete and perfect religion, addressing beliefs and practices. This doctrine implies that Islam regards itself as an inclusive code of behavior for individuals and society with a legal system that covers all issues of social and personal behavior. Therefore, Islam requires a systematic method for understanding universal and comprehensive legal and jurisprudential principles to provide legal answers to all legal problems and questions at all times. The doctrine of ijtihad cannot be limited to formulating the rule of law and resolving legal issues only by using traditional sources. ${ }^{21}$

Traditional methodological principles and istinbat legal norms are preserved and considered invalid if it does not know Muqaddamät (foreword) ijtihad which defined in the literature of usul al-fiqh traditional. While The traditionalism preserves the inability of Islamic law, it also recognizes the need for change and seeks new interpretations. This attempts to introduce a balance into

${ }^{20}$ Mathias Rohe, "Application of the Sharia Rules in Europe Scope and Limits," in Die Welt des Islams, 3 ed., Vol. 44 (Leiden: Koninklijke Brill NV, 2004), 326-28.

${ }^{21}$ A Ezzati, "Islamic Law and the Challenges of Modern Times," Shi'a Islamic Studies 3, no. 1 (2010): 43. 
traditional interpretations while opposing rethinking jurisprudence by using Islamic modernism. ${ }^{22}$

The legal system cannot meet the challenges of time and location unless it is fully aligned with human intelligence ('aql); primordial nature of man (fitrah); human rights; and human, mental, psychological, and spiritual needs of individuals and communities. I believe that the Islamic legal system can meet these challenges as long as the thoughts and approaches of Islamic law are reconstructed and revised according to new challenges and requirements. ${ }^{23}$

The existence of local culture and wisdom ('urf) is the main consideration in the development of Islamic law in the fiqh context. Al-Zuhayli stated that 'urf is a common habit rooted in tubers in a community group. ${ }^{24} \mathrm{Frf}$ is a matter that becomes the habit of many people in their worship. Frf takes place in people's lives both in the form of expressions, deeds, actions which leave things behind. The urf consists of several elements such as regularly, reputable, and action. ${ }^{25}$

Ulama makes urf as one of the legal bases to follow the argument of Ibn Mas'ud's hadith, namely Ma raahu al-muslimun hasana fahua 'indallah hasana, wa ma ra'ahu al-muslimin sayyi'a fahuwa indallah sayy. (what is considered good by Muslims then he is good according to Allah, and what is considered bad for Muslims, then bad according to Allah ${ }^{26}$. While the rules of fiqh in understanding the use of 'urf include:

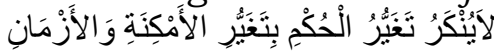

Which means "Can't denied that the changes to the law (related) with a change of venue and time.

العادة المطر دة في نا حيت لا"

which means that" habit is the habit of a place, it's not a signal ".

The authorities urf be one manifestation of openness Islam in overcoming new problems that have never happened before. This is the main basis of epistemology that is interrelated with the Islamic

22 Ashk Dahlén, Islamic Law, Epistemology and Modernity: Legal Philosophy in Contemporary Iran, Middle East Studies: History, Politics, and Law (New York: Routledge, 2003), 115-16.

23 "Islamic Law and the Challenges of Modern Times," 48.

24 Wahbat al-Zuhaili, Ushul al-Fiqh (Beirut: Dar al-Fikr, 1986).

25 Abd al-Wahab Khallaf, Im al-Ushul al Fiqh (Cairo: Dar al-Qalam, 1978).

${ }^{26}$ ju II Wahbat al-Zuhaili, Ushul al-Fiqh, (Beirut: Dar al-Fikr, t.t.), 830. 
archipelago. This happens based on the benefit of society. ${ }^{27}$ 'Urf becomes part of the maintenance of a maslahah because urf is a manifestation of a positive tradition that has been applied to a community locus.

The existence of a dialectic of Islam with previous traditions is very diverse. ${ }^{28}$ Recognition of urf which is a local tradition can be seen from some of the acceptance of ijtihad in Arab, Jewish and Christian tribes in accommodating their traditions becoming integral to Islamic law. Imam syafii in qaul qodim and qoul jadid explained that 'urf must be different in every space and time .

Culture, tradition and local wisdom (ürf) which live in the archipelago are part of the realization of the benefit of life while the benefit is the main goal in the Syariat.

A method of ijtihad can be divided into three models. First, ijtihad can appear from all activities related to language studies (semantics). The objective of this method is to find out how to interpret the verses in the Al-Qur'an and Hadith which refer to the fiqh roles. Second, qiya> si> (analogy), an attempt to establish Islamic law which is specifically not contained in the nas\} by analyzing it with the events of the law contained in the nas\} because of legal similarity. ${ }^{29}$ Third, Istis\} la $>h i$, a method of Ijtihad that collects general verses in order to create universal principles to protect or bring benefit. Istis\} la $h$ \} or al-Mas\}lah\} al-Mursalah is a kindness that is judged logically and based on the aim of syara', but there is no instructions in the nas\} that support or reduce it. ${ }^{30}$ The

27 Yudian Wahyudi, Maqasid Shari'a in Political Struggle; Philosophy of Islamic Law from Harvard to Sunan Kalijaga (Yogyakarta: Islamic Boarding School Nawesea Press, 2007), 21.

28 Yusuf al-Qardhawi, Madkal li Dirasah al-Shari'ah al-Islamiyyah (Cairo: Maktabah Wahbah, 2001).

29 Mengenai definisi Qiyas, lebih lanjut baca Muhammad bin Ahmad bin Abi Sahal al-Sarkhasì, Ușūl al-Sarkhasī, (Digital Library, al-Maktabah al-Syāmilah al-Ișdār al-Șānī, 2005), II/174. Abu. Husain al-Bașrì, al-Mu'tamad fí Ușūl Fiqh, (Digital Library, alMaktabah al-Syāmilah al-Ișdār al-Șānī, 2005), II/443. 'Alì bin Muhammad al-Bazdawì alHanafî, Ușul al-Bazdawī, (Digital Library, al-Maktabah al-Syāmilah al-Ișdàr al-Ṣānī, 2005), I/248.

30 Sejauh mengenai perbedaan pendapat di kalangan ulama dalam hal kehujjahan mașlahah mursalah, maka dalam hal ini dapat dikemukakan beberapa pandangan yang berbeda: (Muhammad Roy, Filsafat Hukum al-Țüfi dan Dinamisasi Hukum Islam, (Yogyakarta: Pondok Pesantren UII, 2007), hlm. 58-59). Pertama, Mașlahah mursalah tidak bisa dijadikan dalil hukum (hujjah) secara mutlak dalam hukum Islam. Pendapat ini dipegangi oleh Syāfi'iyah, Ḥanafiyah, Zahiriyah, dan Syi'ah. Madzhab Syafi'i dan Hanafi tidak memasukkan maslahah mursalah ke dalam hierarki pokok-pokok ajaran madzhab mereka. Lihat Manna' al-Qatān, al-Tasyrī' wa al-Fiqh fi al-Islām; Tärīkhan wa Manhājan, 
use of construction of the Indonesian Islamic law epistemology and the model istis $\} l a\}>h\} i>$ is to achieve the sides in the social life by combining the measure of nas\} or text logically, combining between text and tradition (context). The integration of the both aims so that the sides to be achieved are not wild, apart from the corridors of syara 'and only use consideration of reason and mere social reality. In addition, the integration of nass $\}$ and sense is done so that ijtihad is not only dogmatic textual without using realistic and practical benefit considerations.

In terminology, maslahah is a hings that brings goodness, such as an attempt to buy and sell that can bring the seller to profit. Whereas in the terminology specifically the view of Islamic law, that is, the cause that can lead to the achievement of the objectives of Islamic law, whether worship or mualmalah. ${ }^{31}$

The concept of maslahat is one of the important objects in a study of Islamic law. Maslahat is not only a legal method but also becomes a means of achieving the objectives of Islamic law (maqhasid syariah) 32 which subsequently became one of the best methods of resolving unresolved law in the contemporary era into syariah law especially issues that are not explicitly explained in nash that have been present amid human social life 33 .

Al-maslahah murslalah is one of parts of ijtihad which study nash in the Qur'an and al-hadith. All nash has proven that all of its contents are prohibited orders, goodness, benefits, and wisdom to benefit a life ${ }^{34}$.

cet. V, (Kairo: Maktabah Wahbah, 2001), hlm. 331-376. Kedua, Mașlahah Mursalah bisa dijadikan hujjah secara mutlak. Pendapat ini dipegangi oleh Imām Mālik dan Imām Ḥaramain, juga sebagian ulama Ḥanābilah seperti Sulaimān al-Ṭ̂ufi. Pendapat Imam Mālik ini juga dikutip dan diikuti oleh Fakhruddin al-Rāzí. Lihat Fakhruddin al-Rāzí, al-Mahșūl fi Ilm al-Ușūl, (Beirut: Dār al-Kutub al-'Ilmiyah, 1999), II/501. Baca juga Ali Hasballah, Ușūl al-Tasyrī' al-Islāmī, (Kairo: Dār al-Fikr al-'Arabī, 1997, hml. 151). Ketiga, Maslahah Mursalah dapat dijadikan hujjah dalam hukum Islam asalkan memenuhi tiga syarat, yaitu ḍarūriyāt, qat'iyāt, dan kulliyāt. Pendapat ini dipegangi oleh al-Ghazāii. (Abu Hạamid alGhazāii, al-Mustașfā, [Beirut: Dār al-Kutub al-'Ilmiyah, 1993], hlm. 181).

31 At-Tufy sulaiman majmuddin, At-Ta'yin fi Syarhi Al-Arabin (Beirut: Muassasah Dayyan, 1998), 239.

32 Agil Bahsoan, MASHLAHAH SEBAGAI MAQASHID AL SYARIAH, $2011,20$.

33 Yusuf Ahmad Muhammad al-Badawi, Maqashid al-Syariah inda Ibn Taymiyah (Yordania: Dar al-Nafais, 1999).

34 Mohammad Abu Zahroh, Ushul Fiqh (Beirut: Daar Al-Fkr Al-Araby, tt). 
Mashlahah to convey the same kindness and benefit under the auspices of the key principles (al-Kulliyat 35 al-khams), namely hifdz al-diN (maintaining the religion), hifdz al-'aql (maintaining reasonable), hifdz al -nafs (nourishes the soul), hifdz al-māl (maintaining the property) and hifdz al-'ird (the breeding).

As other analytical methods, maslahah is also a method of istinbat approach (legal stipulation) which is not regulated in much detail and explicitly in the Qur'an and al hadith. This method emphasizes the aspect of maslahah directly. ${ }^{36}$

There are many fiqh principles that discuss the importance of maslahah in Islamic law itself.

درء المفاسد مقدم على جلب مصالح benefit"

Which means "Refuse damage precedence rather than bring الضَتَرَرُ يُزَالُ

Which means "evil must be removed".

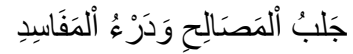

Which means "achieving benefit and rejecting obedience".

The comprehension of kaidah previously last mentioned has a meaning that the whole thing is contained beneficiaries is a command by the Shari'a and the rest of the mafsadat is prohibited by law. As for the benefit in terms of sharia, it can be divided into three, which are obligatory, sunnah and some are alms to be implemented. Likewise, mafsadah, there is also an unlawful haram to be carried out. The more concrete measures can be studied in maqashid sharia in detail.

The characteristics of the Islamic Shari'a are dimensions: include world-hereafter, material-spiritual, and make religion the main problem. While the standard proposed three trends above and the characteristics are just the opposite. Tends to be worldly and

35 Felicitas Meta Maria Opwis, Maslaha and Purpose in The Law: Islamic Discourse on Legal Change from The 4th/10th to 8th/14th Century (Boston: Brill, 2010).

36 Hasbi Umar, Nalar Figh Kontemporer (Jakarta: Gaung Persada Press, t.t.). 
materialistic only and tends to make religion a tool to refer to these materialistic materialities. ${ }^{37}$

The journey of the maslahat in the modern era, tends to strengthen the maslahat as a method that displaces the rigidity of Islamic law, and supports Islamic law that is adaptive to change. In the midst of such a tendency, there are also some writers who try to limit the use of the maslahat method again. In 1965, Sa'id Ramadlan al-Buthiy, issued his dissertation work at Al-Azhar, entitled Dlawabith al-Mashalahah. ${ }^{38}$ In his dissertation, he began his presentation by mentioning that Orientalists had begun a new model of his attack on Islam by advocating the opening of the door to ijtihad as widely as possible and emphasizing that the method of maslahat was a very fundamental method to become a reference. Related to this issue, Al-Buthiy said that the ijtihad was never closed, and Allah also greatly appreciated the benefit. However, benefit still has limitations and qualifications. The use of the maslahat method should follow the regulations because it is fenced by various rules which it is called as 'dlawabith al-mashlahah'. The rules of Dawābit al-Mașlah itself are : 1) accentuating the objective of syara'; 2) uncontradictory with Qur'an; 3) uncontradictory with Al Sunnah; 4) uncontradictory with the qiyas principle; 5) commonwealth. 39

\section{Conclusion}

37 Yusuf Ahmad Muhammad al-Badawi, Maqashid al-Syariah inda Ibn Taymiyah.

38 Musthafa al-Zarqa' mengatakan bahwa kitab ini merupakan kitab terbaik yang berbicara tentang maslahat. Lihat Musthafa al-Zarqa', AlIstishlah, bagian muqaddimah. Khalid Masud memberikan catatan, AlButhiy seringkali merujuk pada al-Muwafaqat-nya Syatibi, namun dalam mengutip Buthiy ternyata sangat selektif dan seringkali tidak sesuai konteksnya (out of context). Kelemahan lain karya Al-Buthiy adalah ia telah gagal untuk memaparkan secara utuh tentang pentingnya konsep maslahat, sebab ia kurang memberikan perhatian terhadap argumenargumen yang mendukung konsep tersebut seperti Syatibi. Khalid, 180. Berkaitan tentang penilaian Khalid Masud yang terakhir, menurut kami, hal ini karena memang Al-Buthiy tidak sedang membicarakan urgensi konsep ini, sebab bukunya tersebut sedang membicarakan 'aturan main' penggunaan konsep maslahat dalam legislasi, sehingga wajar jika AlButhiy tidak secara detail berbicara tentang urgensi konsep ini. Dengan kata lain, adalah tidak pada tempatnya, jika Khalid Masud menilai hal tersebut sebagai kelemahan karya Al-Buthiy, meskipun kritiknya yang pertama atas karya Al-Buthiy ini tetap layak dipertimbangkan dan didiskusikan lagi.

39 Ramadhan al-Buthy, Ibid halaman 119-161. 
The time heads to the no-longer vivid differentiation of civilization among nations. That means the available problems are more various and uncontrollable. In order to bridge the solution of the problems in the globalization era the thing needed is the reactualization of the fiqh methodes that are related to human relation to tradition of ones' habitat that will then result an appropriate fiqh. Indonesian Ushul Fiqh offers a wider space to tradition in the forming of fiqh. At the end, the related tradition must be able to a vessel in reaching the goal of fiqh, that is for the betterment of the people. Upon the public betterment, then the existing problems could resolve a beneficial solution for individuals, groups and surroundings[.]

\section{Bibliography}

A Ezzati. "Islamic Law and the Challenges of Modern Times." Shi'a Islamic Studies 3, no. 1 (2010): 43.

Abd al-Wahab Khallaf. Ilm al-Ushul al Figh. Cairo: Dar al-Qalam, 1978.

Abdillah, Junaidi. "Rekonstruksi Epistemologi Fiqh Jinâyah Indonesia Dan Relevansinya Bagi Pembangunan Hukum Nasional." AL-'ADALAH 11, no. 2 (2013): 187-204.

Abdurrahman bin Sa'ad al-Syhstariy. Taqnin al-Shari'ah Bain al-Tahlil wa alTahrim, t.t.

Abu al-Sa'adat al-Mubarak bin Muhammad al-Jaziriy. al-Nihayah fi Gharib al-Astar. Vol. 5. Baerut: al-Maktabah al-Ilmiyah, 1979.

Agil Bahsoan. MASHLAHAH SEBAGAI MAQASHID AL SYARIAH, 2011.

Ahmad Syafii Maarif. Islam in the Frame of Indonesianness and Humanity: A Reflection of History. Bandung: Mizan Collaborating with the Maarif Institute, 2009.

Akhmad Sahal. Nusantara Islam From Ushul Figh to Paham Kebangsaan. Bandung: Mizan Library, 2015.

Al-Nadwah al-Alamiyah lsyabab al-Islamiy. "al-Mausu'ah al-Muyassarah fi al-Adyan wa al-Azahib wa al-Ahzab" volume 22 (t.t.): 16.

Ashk Dahlén. Islamic Law, Epistemology and Modernity: Legal Philosophy in Contemporary Iran, Middle East Studies: History, Politics, and Law. New York: Routledge, 2003.

At-Tufy sulaiman majmuddin. At-Ta'yin fi Syarhi Al-Arabin. Beirut: Muassasah Dayyan, 1998.

Azyumardi Azra. “Sustainable Indonesian Islam.” Kompas, 3 Agustus 2015. Denzin, Norman K., dan Yvonna S. Lincoln. Hand Book of Qualitative Research. Yogyakarta: Pustaka Pelajar, 2009.

Hasbi Umar. Nalar Figh Kontemporer. Jakarta: Gaung Persada Press, t.t. 
Hikamat bin Basyir bin Yasin. Samahah al-Islam fi al-Ta'amul ma'a ghair alMuslimin, t.t.

Imam Mustofa. "Epistemology Hukum Islam dalam Perspektif al-Ghazali (Telaah atas f Kitab al-Mustashfa min 'Ulmul Ushul)." an -Nawa Jurnal Hukum Islam 4, no. 1 (t.t.): 2009.

ju II Wahbat al-Zuhaili. Ushul al-Figh, Beirut: Dar al-Fikr, t.t.

Krippendorff, Klaus. Content Analysis; an Indtroduction to Its Methodology. London: Sage Publication, 2004.

M Amin Abdullah. "NEW BUILDING OF EVIDENCE EPISTEMOLOGY ISLAMIC LAW STUDY IN RESPONDING GLOBALIZATION." AshSyir'ah Journal of Shariah Sciences and Law 46 (2012): 326.

Muhammad bin Abdillah bin Shalih al- Sahim. al-Islam Usul wa Mabadi'uh. al-Mamlakah al-Arabiyah al-Su'udiyah, Wazair al-Syu'un al-Islamiyah wa al-Auqaf wa al-Dakwah wa al-Irshad, $1421 \mathrm{H}$.

Muhammad Guntur Ramli. Our Islam, Nusantara Islam Five Basic Values of Nusantara Islam, (: ), edition., h. 1 ed. Tanggerang: Ciputat School, 50.

Pizzaro, N. Tauhidi. Islam Nusantara: Islamisasi Nusantara atau Menusantarakan Islam? Jakarta: T.tp, 2015.

Wahbat al-Zuhaili. Ushul al-Figh. Beirut: Dar al-Fikr, 1986.

Yudian Wahyudi. Maqasid Shari'a in Political Struggle; Philosophy of Islamic Law from Harvard to Sunan Kalijaga. Yogyakarta: Islamic Boarding School Nawesea Press, 2007.

Yusuf al-Qardhawi. Madkal li Dirasah al-Shari'ah al-Islamiyyah. Cairo: Maktabah Wahbah, 2001. 